\title{
PENERAPAN MODEL PEMBELAJARAN INKUIRI TERBIMBING UNTUK MENINGKATKAN KETERAMPILAN PROSES SAINS SISWA PADA KONSEP LARUTAN ELEKTROLIT DAN NONELEKTROLIT
}

\author{
Arisna Oktavia Dijaya ${ }^{1}$, Ratih Pitasari ${ }^{2}$ dan Siti Kurniasih ${ }^{\mathbf{3}}$ \\ ${ }^{7}$ Program Studi Pendidikan Kimia, Jurusan Pendidikan MIPA, Fakultas Tarbiyah dan \\ Keguruan, UIN Sunan Gunung Djati Bandung, Jl. A. H. Nasution No. 105, Bandung, 40614, \\ Indonesia \\ ${ }^{2}$ SMA Negeri 16 Bandung, Jalan Mekar Sari No. 81, Babakan Sari, Kiaracondong, Kota \\ Bandung, 40283, Indonesia \\ ${ }^{3}$ SMA Negeri 10 Bandung, Jalan Cikutra No. 77, Cikutra, Cibeunying Kidul, Kota Bandung, \\ 40124, Indonesia \\ ${ }^{1}$ E-mail: Arisnadijaya@gmail.com
}

\begin{abstract}
ABSTRAK
Penelitian ini bertujuan untuk mendeskripsikan aktivitas siswa untuk setiap siklus pada proses pembelajaran inkuiri terbimbing, kinerja siswa untuk setiap siklus sesuai tahapan inkuiri terbimbing, dan keterampilan proses sains untuk setiap siklus dengan model inkuiri terbimbing. Metode penelitian yang digunakan adalah penelitian tindakan kelas. Subjek penelitian 35 siswa kelas X IPA-4 SMAN 10 Bandung. Instrumen yang digunakan adalah deskripsi pembelajaran, lembar kerja siswa, format penilaian aktivitas siswa, guru, aspek psikomotor siswa, dan tes evaluasi keterampilan proses sains. Data yang diperoleh diolah menggunakan statistik deskriptif. Penerapan model pembelajaran inkuiri terbimbing dilaksanakan sesuai deskripsi pembelajaran. Hasil penelitian menunjukkan penerapan model pembelajaran inkuiri terbimbing pada konsep larutan elektrolit dan nonelektrolit untuk meningkatkan keterampilan proses sains terimplementasikan dengan baik. Jumlah rata-rata aktivitas siswa selama pembelajaran mengalami peningkatan pada setiap siklusnya. Pada siklus I nilai rata-rata aktivitas siswa sebesar 86,4 (sangat baik) dan siklus II 91 (sangat baik). Melaksanakan pekerjaan LKS dengan benar untuk setiap siklus sehingga pembelajaran inkuiri terbimbing pada konsep larutan elektrolit dan nonelektrolit mengalami peningkatan. Nilai rata-rata siklus I sebesar 70 (baik) dan siklus II sebesar 75 (baik). Peningkatan keterampilan proses sains siswa pada siklus I dan II dengan nilai rata-rata siklus I yaitu 67 (cukup) dan siklus II yaitu 70 (baik).
\end{abstract}

Kata kunci: model pembelajaran inkuiri terbimbing, keterampilan proses sains, larutan elektrolit dan nonelektrolit. 
Penerapan Model Pembelajaran Inkuiri Terbimbing untuk Meningkatkan Keterampilan Proses Sains Siswa pada Konsep Larutan Elektrolit dan Nonelektrolit

\begin{abstract}
This study aims to describe the activities of students for each cycle in the guided inquiry learning process, student performance for each cycle according to guided inquiry stages, and science process skills for each cycle with a guided inquiry model. The research method used is classroom action research. The research subjects were 35 grade $X$ students of IPA-4 SMAN 10 Bandung. The instruments used were description of learning, student worksheets, format for assessing student activities, teachers, psychomotor aspects of students, and tests of evaluation of science process skills. The data obtained is processed using descriptive statistics. The application of a guided inquiry learning model is carried out according to the description of learning. The results showed that the application of a guided inquiry learning model to the concept of electrolyte and non-electrolyte solutions to improve science process skills was well implemented. The average number of student activities during learning increases in each cycle. In the first cycle the average value of student activities was 86.4 (very good) and cycle II 91 (Very good). Carry out the LKS work correctly for each cycle so that guided inquiry learning on the concept of electrolyte and non-electrolyte solutions has increased. The average value of cycle I is 70 (Good) and cycle II is 75 (good). Improvement of students' science process skills in the first and second cycles with the average value of the first cycle that is 67 (sufficient) and the second cycle is 70 (good).
\end{abstract}

Keywords: guided inquiry learning models, science process skills, electrolyte solutions and nonelectrolytes.

DOI: https://doi.org/10.15575/jtk.v3i2.3597

\title{
1. PENDAHULUAN
}

Salah satu cabang IPA adalah ilmu kimia. IImu kimia merupakan ilmu yang diperoleh dan dikembangkan berdasarkan eksperimen yang mencari jawaban atas pertanyaan apa, mengapa, dan bagaimana gejala-gejala alam, khususnya yang berkaitan dengan komposisi, struktur dan sifat, transformasi dinamika dan energetika zat (Kemendikbud, 2016).

Pada proses pembelajaran kimia di kelas, sekitar 65\% siswa masih kurang aktif dan cenderung pasif dikarenakan kurangnya dorongan dan motivasi guru dalam pembelajaran (Dimyati, 2015). Ketika siswa diberikan pertanyaan, masih sedikit siswa atau sekitar $21 \%$ yang mencoba untuk menjawab pertanyaan. Demikian juga sebaliknya ketika diberikan kesempatan untuk bertanya, siswa masih ada yang belum berani mengungkapkan pertanyaan. Sehingga pembelajaran di kelas masih kurang efektif ditinjau dari keaktifannya.

Kendala lain diantaranya yaitu dalam pembelajaran guru belum menyediakan bimbingan atau petunjuk yang cukup luas kepada siswa. Oleh karena itu siswa masih belum dapat merumuskan masalah dan hipotesis dalam LKS yang diberikan. Selain itu, siswa masih mengalami kesulitan dalam memahami materi karena kemampuan berpikir siswa dalam membangun konsep masih belum sepenuhnya tercapai. Serta kegiatan praktikum yang tidak bisa selalu dilakukan karena keterbatasan alat dan bahan. Sedangkan nilai KKM yang telah ditetapkan untuk mata pelajaran kimia yaitu 70, namun berdasarkan data nilai kimia sebelumnya $60 \%$ siswa masih berada dibawah nilai KKM.

Salah satu konsep dalam pembelajaran kimia adalah konsep larutan elektrolit dan nonelektrolit. Larutan elektrolit dan nonelektrolit mengandung konsep yang bersifat abstrak contoh konkret (Fathan dkk., 
Penerapan Model Pembelajaran Inkuiri Terbimbing untuk Meningkatkan Keterampilan Proses Sains Siswa pada Konsep Larutan Elektrolit dan Nonelektrolit

2013) misalnya peristiwa pelarutan, ionisasi dan disosiasi larutan elektrolit, serta hantaran listrik larutan. Konsep yang bersifat abstrak ini tidak jarang membuat siswa merasa kesulitan dalam mempelajarinya (Calik dan Ayas, 2005).

Pembelajaran yang diberikan harus dapat membuat siswa aktif dalam proses membangun konsep. Serta menyajikan proses pembelajaran yang relevan dan menyenangkan. Maka akan menghasilkan pengalaman belajar yang dapat meningkatkan motivasi siswa untuk belajar sehingga dapat meningkatkan keterampilan siswa (Warsono dan Hariyanto, 2012).

Upaya yang dapat dilakukan untuk meningkatkan hasil belajar siswa adalah guru merancang suatu pembelajaran yang dapat meningkatkan keterampilan proses sains siswa. Salah satu desain pembelajaran yang dapat membangun pengetahuan siswa secara mandiri yaitu pembelajaran inkuiri. Salah satu tipe inkuiri yang menekankan pada pengalaman belajar adalah inkuiri terbimbing (Hanson, 2006).

Berdasarkan hasil penelitian McDonnell (2013) menunjukkan bahwa inkuiri terbimbing dapat mendorong siswa menjadi peserta didik yang mandiri dan beripikir kritis pada pembelajaran kimia. Inkuiri terbimbing dapat meningkatkan keterampilan berpikir tingkat tinggi siswa, keterampilan pemecahan masalah serta motivasi siswa dalam pembelajaran kimia. Pembelajaran yang melibatkan aktivitas dalam inkuiri terbimbing mengakibatkan siswa tidak merasa jenuh dalam proses pembelajarannya. Salah satu tujuan yang ingin dicapai dengan diterapkannya inkuiri terbimbing pada penelitian ini yaitu untuk meningkatkan keaktifan dan hasil belajar siswa di kelas.
Kemampuan keterampilan proses sains berguna untuk siswa dapat mengintegrasikan hasil penelitian ilmiahnya dengan konsep yang telah dipelajari. Siswa harus bekerja memecahkan masalah, menemukan segala sesuatu bagi dirinya dan berusaha dengan ide-idenya agar siswa benar-benar memahami dan dapat menerapkan pengetahuannya (Mulyasa, 2011).

Berdasarkan beberapa hal yang telah dikemukakan, peneliti menganggap perlu dilakukan suatu penelitian untuk mengatasi keaktifan siswa di kelas, kemampuan guru dalam mengelola pembelajaran dan membangun pengetahuan siswa maka diperlukan suatu pendekatan yang tepat untuk meningkatkan keterampilan proses sains melalui pengalaman belajar.

Siswa diharapkan dapat meningkatkan keterampilan proses sains, yang meliputi sepuluh indikator, mengamati, menafsirkan, mengklasifikasi, mengajukan pertanyaan, memprediksi, membuat hipotesis, merancang penyelidikan, mengkomunikasikan, menerapkan konsep, dan keterampilan menyimpulkan (Farida, 2014). Indikator tersebut menjadi tolak ukur sejauh mana keterampilan proses sains yang siswa miliki.

Berdasarkan uraian di atas, peneliti tertarik untuk menerapkan pembelajaran inkuiri terbimbing tersebut pada konsep larutan elektrolit dan nonelektrolit, untuk meningkatkan aktivitas, hasil belajar dan keterampilan proses sains siswa.

Tujuan penelitian ini adalah sebagai berikut: (1) mendeskripsikan aktivitas siswa untuk setiap siklus pada proses pembelajaran inkuiri terbimbing pada konsep larutan elektrolit dan nonelektrolit di kelas X IPA-4 SMAN 10 Bandung; (2) menganalisis kinerja siswa dalam menyelesaikan LKS setiap tahap 
Penerapan Model Pembelajaran Inkuiri Terbimbing untuk Meningkatkan Keterampilan Proses Sains Siswa pada Konsep Larutan Elektrolit dan Nonelektrolit

pembelajaran inkuri terbimbing pada konsep larutan elektrolit dan nonelektrolit untuk setiap siklus di kelas X IPA-4 SMAN 10 Bandung; (3) menganalisis keterampilan proses sains siswa pada konsep larutan elektrolit dan nonelektrolit untuk setiap siklus setelah pembelajaran inkuiri terbimbing di kelas X IPA-4 SMAN 10.

Teori yang terdapat dalam ilmu kimia mempelajari tentang bangun (struktur), susunan, sifat, dan perubuhan materi yang menyangkut level makroskopis, mikroskopis (atom, ion, molekul), dan simbolik (lambang, rumus kimia, persamaan kimia, grafik, diagram) (McMurry, 2012). Oleh karena itu diperlukan suatu kemampuan penalaran yang lebih tinggi agar dapat memahami konsep kimia.

Model pembelajaran inkuiri terbimbing adalah pembelajaran inkuiri dengan bimbingan guru, yakni suatu cara penyampaian pembelajaran dengan penelaahan sesuatu yang bersifat pencarian secara kritis, analitis dan argumentatif secara ilmiah dengan menggunakan langkahlangkah identifikasi masalah, perumusan masalah, perumusan hipotesis, siswa mencari informasi, data, fakta yang diperlukan, menguji hipotesis dan menarik kesimpulan jawaban (Mulyasa, 2011).

Keterampilan proses sains merupakan seperangkat keterampilan yang melibatkan keterampilan intelektual, manual dan sosial, mencakup kemampuan mengamati, menafsirkan, mengklasifikasi, mengajukan pertanyaan, memprediksi, membuat hipotesis, merancang penyelidikan, mengkomunikasikan, menerapkan konsep, dan keterampilan menyimpulkan yang digunakan untuk membangun pemahaman terhadap suatu konsep/ gagasan/ pengetahuan dan meyakinkan/ menyempurnakan pemahaman yang sudah terbentuk (Rustaman dalam Farida, 2014).

Larutan elektrolit adalah suatu zat yang ketika dilarutkan dalam air akan menghasilkan larutan yang dapat menghantarkan arus listrik dan larutan nonelektronit tidak menghantarkan arus listrik ketika dilarutkan dalam air (Chang, 2005). Dengan membandingkan cahaya bola lampu pijar dari zat-at terlarut dengan jumlah molar yang sama dapat membantu kita untuk membedakan antara elektrolit kuat dan elektrolit lemah.

\section{METODE PENELITIAN}

Metode yang digunakan dalam penelitian ini adalah penelitian tindakan kelas yang sebelumnya mengidentifikasi permasalahan yang dialami guru kimia. Penelitian tindakan kelas ini terdiri dari empat komponen kegiatan pokok yaitu: (a) perencanaan (planning); (b) tindakan (acting); (c) pengamatan (observing); (d) refleksi (reflecting). Pada pelaksanaannya, keempat komponen kegiatan pokok itu berlangsung secara terus-menerus atau disebut siklus, hal ini yang menjadikan ciri dari penelitian tindakan kelas (Arikunto, 2013)

Subjek dalam penelitian adalah siswa SMA Negeri 10 Bandung kelas X IPA IV. Instrumen yang digunakan dalam penelitian ini adalah deskripsi pembelajaran, LKS (Lembar Kerja Siswa) inkuiri terbimbing, lembar observasi guru dan siswa, dan tes keterampilan proses sains.

\section{HASIL DAN PEMBAHASAN}

Proses pembelajaran inkuiri terbimbing pada konsep larutan elektrolit dan nonelektrolit dilakukan dalam dua siklus meliputi tahapan identifikasi masalah, perumusan masalah, 
Penerapan Model Pembelajaran Inkuiri Terbimbing untuk Meningkatkan Keterampilan Proses Sains Siswa pada Konsep Larutan Elektrolit dan Nonelektrolit

perumusan hipotesis, mengumpulkan data dan verifikasi hasil dan penarikan kesimpulan. Konsep larutan elektrolit dan nonelektrolit pada siklus I yaitu materi identifikasi larutan elektrolit dan nonelektrolit dengan uji daya hantar listrik, dengan refleksi hasil pembelajaran diantaranya memperbaiki pengelolaan kelas, variasi kelompok belajar siswa dan merubah penggunaan media pembelajaran dengan video setelah refleksi dilakukan perbaikan RPP, LKS dan alat evaluasi kemudian dilanjutkan dengan siklus II yaitu materi jenis dan sifat larutan elektrolit dan nonelektrolit.

Penilaian aktivitas siswa setiap tahap pembelajaran inkuiri terbimbing pada konsep larutan elektrolit dan nonelektrolit untuk tiap siklus diperoleh dari penilaian lembar observasi aktivitas siswa yang diamati pada saat pembelajaran berlangsung diantaranya interaksi siswa dan guru, teknik bertanya, kinerja siswa ketika praktikum. Berikut ini merupakan hasil analisis aktivitas siswa kelas $X$ IPA-IV SMAN 10 Bandung yang disajikan pada Tabel 1.

Tabel 1. Nilai Rata-rata Aktivitas Kelompok Belajar Setiap Siklus

\begin{tabular}{|c|c|c|}
\hline \multirow{2}{*}{$\begin{array}{c}\text { Kelompok } \\
\text { Belajar }\end{array}$} & \multicolumn{2}{|c|}{ Nilai LKS } \\
\cline { 2 - 3 } Magnesium & Siklus I & Siklus II \\
\hline Boron & 86 & 92 \\
\hline Nitrogen & 82 & 91 \\
\hline Karbon & 93 & 96 \\
\hline Natrium & 82 & 95 \\
\hline Rata-rata & 86,4 & 85 \\
\hline
\end{tabular}

Hasil observasi aktivitas siswa pada siklus II menunjukkan siswa sudah mulai aktif dan antusias dalam KBM dengan menggunakan inkuiri terbimbing. Pada siklus II, rata-rata keaktifan siswa adalah 91. Hal ini menunjukkan adanya peningkatan aktivitas siswa pada proses pembelajaran inkuiri terbimbing pada setiap siklusnya. Beberapa kelompok sudah antusias dalam mengerjakan LKS inkuiri terbimbing, dan siswa sudah mengerti dengan tugas yang diberikan. Siswa pun aktif berdiskusi dengan kelompoknya maupun dengan kelompok lain.

Penilaian keterampilan proses sains siswa setiap tahap pembelajaran inkuiri terbimbing pada konsep larutan elektrolit dan nonelektrolit untuk tiap siklus diperoleh dari penilaian LKS pembelajaran yang dikerjakan oleh siswa dengan kelompoknya yang akan disajikan pada Tabel 2.

Tabel 2. Nilai Rata-rata Aktivitas Kelompok Belajar Setiap Siklus

\begin{tabular}{|c|c|c|}
\hline \multirow{2}{*}{$\begin{array}{c}\text { Kelompok } \\
\text { Belajar }\end{array}$} & \multicolumn{2}{|c|}{ Nilai LKS } \\
\cline { 2 - 3 } Magnesium & Siklus I & Siklus II \\
\hline Boron & 91 & 92 \\
\hline Nitrogen & 67 & 95 \\
\hline Karbon & 87 & 92 \\
\hline Natrium & 71 & 95 \\
\hline Rata-rata & 76 & 92 \\
\hline
\end{tabular}

Berdasarkan Tabel 2, hasil analisis keterampilan proses sains siswa setiap tahap pembelajaran inkuiri terbimbing pada konsep larutan elektrolit dan noneleketrolit untuk setiap siklus mengalami peningkatan dengan nilai rata-rata siklus I 76 dan siklus II 93, akan tetapi seluruh kelompok belajar lebih berperan aktif pada tahap pelaksanaan percobaan, hal ini dikarenakan melalui percobaan siswa mampu menemukan sendiri teori yang telah dipelajarinya, selain itu juga dapat melatih siswa cara berpikir ilmiah (Putra, 2013). Interpretasi hasil analisis data perolehan kinerja siswa dalam penyelesaian LKS dari setiap siklus disajikan dalam tabel hasil kinerja LKS untuk setiap siklus ditunjukkan pada Tabel 3 dan Tabel 4.

Berdasarkan hasil analisis LKS dari setiap siklusnya. Pada siklus I dan II, tahapan yang 
Penerapan Model Pembelajaran Inkuiri Terbimbing untuk Meningkatkan Keterampilan Proses Sains Siswa pada Konsep Larutan Elektrolit dan Nonelektrolit

memperoleh nilai terendah pada siklus I yaitu merumuskan masalah hal ini terjadi karena guru belum menyediakan bimbingan atau petunjuk yang cukup luas kepada siswa. Tahap yang memperoleh nilai terendah pada siklus II, adalah perumusan masalah. Tetapi nilai rata-rata dari siklus I ke siklus II ada peningkatan yaitu siklus I 60 dan siklus I| 65 .
Adanya peningkatan nilai tersebut dikarenakan pada siklus II meskipun guru menjelaskan secara rinci bagaimana cara merumuskan masalah dari sebuah wacana pada siklus I dan gambar pada siklus II, siswa masih belum terbiasa merumuskan masalah dari sebuah wacana dengan tepat.

Tabel 3. Nilai LKS Kelompok Belajar Berdasarkan Siklus I

\begin{tabular}{|c|c|c|c|c|c|c|}
\hline \multirow{2}{*}{ Kelompok Belajar } & \multicolumn{5}{|c|}{ Nilai LKS } & \multirow{2}{*}{$\begin{array}{c}\text { Rata- } \\
\text { rata }\end{array}$} \\
\cline { 2 - 6 } & *T1 & *T2 & *T3 & *T4 & *T5 & *To \\
\hline Magnesium & 50 & 50 & 64 & 64 & 75 & 70 \\
\hline Boron & 75 & 75 & 75 & 63,5 & 100 & 68 \\
\hline Nitrogen & 75 & 50 & 50 & 66 & 68 & 71.8 \\
\hline Karbon & 50 & 83 & 50 & 68 & 100 & 60 \\
\hline Natrium & 50 & 50 & 100 & 75 & 100 & 75 \\
\hline Rata-rata & 70 & 60 & 70 & 70 & 80 & 70 \\
\hline
\end{tabular}

Tabel 4. Nilai LKS Kelompok Belajar Berdasarkan Siklus II

\begin{tabular}{|c|c|c|c|c|c|c|}
\hline \multirow{2}{*}{ Kelompok Belajar } & \multicolumn{5}{|c|}{ Nilai LKS } & \multirow{2}{*}{$\begin{array}{c}\text { Rata- } \\
\text { rata }\end{array}$} \\
\cline { 2 - 6 } & ${ }^{*} \mathbf{T 1}$ & ${ }^{*} \mathbf{T} 2$ & ${ }^{*} \mathbf{T 3}$ & ${ }^{*} \mathbf{T 4}$ & ${ }^{*} \mathbf{T 5}$ & 50 \\
\hline Magnesium & 50 & 100 & 100 & 50 & 50 & 72 \\
\hline Boron & 100 & 50 & 50 & 83 & 100 & 77 \\
\hline Nitrogen & 50 & 75 & 100 & 67 & 100 & 78 \\
\hline Karbon & 67 & 50 & 50 & 100 & 83 & 70 \\
\hline Natrium & 100 & 50 & 75 & 67 & 100 & 78 \\
\hline Rata-rata & 73,4 & 65 & 75 & 73,4 & 87 & 75 \\
\hline
\end{tabular}

*Keterangan: *T1: tahap identifikasi masalah, *T2: tahap merumuskan masalah, ${ }^{*}$ T3: tahap mendefinisikan hipotesis, ${ }^{*} \mathrm{~T} 4$ : tahap mengumpulkan data, ${ }^{*}$ T5: tahap verfikasi hasil dan penarikan kesimpulan.

Menurut Ausabel (dalam Riyanto, 2010), ketika siswa tidak dapat menemukan informasi yang sifatnya abstrak, umum dan inklusif, maka akan terjadi kesulitan untuk merumuskan dan mengorganisasikan materi demi materi dalam struktur yang logis dan mudah dipahami.

Tahapan yang memperoleh nilai tertinggi pada siklus I adalah tahap verifikasi hasil dan penarikan kesimpulan. Nilai rata-rata 80. Hal ini dikarenakan pada tahapan ini siswa telah mendapatkan banyak informasi yang dibutuhkan dari berbagai literatur. Pada siklus II yaitu tahap verifikasi hasil dan penarikan kesimpulan, memiliki nilai tertinggi dengan nilai rata-rata 87 .

Menurut Bruner (dalam Fitriyani, 2015), cara belajar yang menuntut siswa agar dapat berpartisipasi aktif dengan konsep dan prinsip-prinsip yang diperoleh dari pengalaman dan eksperimen-eksperimen yang mereka temukan sendiri untuk menyelesaikan masalah dan akan menghasilkan pengetahuan yang dapat bertahan lama. Berdasarkan hasil analisis LKS kelompok belajar pada setiap siklus, Jurnal Tadris Kimiya 3, 2 (Desember 2018): 190-198

This is an open access article under CC-BY-SA license (https://creativecommons.org/licenses/by-sa/4.0/) 
Penerapan Model Pembelajaran Inkuiri Terbimbing untuk Meningkatkan Keterampilan Proses Sains Siswa pada Konsep Larutan Elektrolit dan Nonelektrolit

diperoleh nilai rata- rata LKS untuk setiap siklusnya yaitu dapat dilihat dalam Gambar 1 .

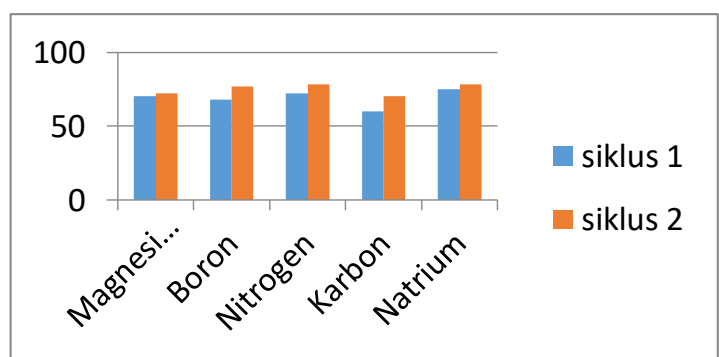

Gambar 1. Grafik Nilai Rata-rata LKS Kelompok Belajar pada Setiap Siklus

Dari hasil analisis indikator keterampilan proses sains peneliti menemukan hubungan antara tahap pembelajaran inkuiri terbimbing dan indikator keterampilan proses sains, seperti yang terlihat pada Tabel 5 .

Indikator keterampilan proses sains (KPS) siswa melalui pembelajaran inkuiri terbimbing secara umum mengalami peningkatan pada tiap tahapnya. Namun analisis peningkatan indikator keterampilan proses sains melalui LKS hanya menjelaskan peningkatan keterampilan proses sains siswa dalam kelompok. Sedangkan untuk mengukur peningkatan keterampilan proses sains siswa secara individu yaitu melalui soal keterampilan proses sains. Adapun indikator keterampilan proses sains siswa secara individu diukur melalui tes soal keterampilan proses sains, setiap soal merepresentasikan

Tabel 5. Hubungan Tahap Inkuiri Terbimbing Dengan Indikator Keterampilan Proses Sains.

\begin{tabular}{|c|c|c|c|c|}
\hline \multirow{2}{*}{ No } & \multirow{2}{*}{ Tahap Pembelajaran Inkuiri } & \multirow{2}{*}{ Indikator KPS } & \multicolumn{2}{|c|}{ Nilai Rata-rata } \\
\hline & & & Siklus I & Siklus II \\
\hline 1 & Identifikasi masalah & Mengamati & 70 & 73 \\
\hline 2 & Merumuskan masalah & Menqajukan pertanyaan & 60 & 65 \\
\hline 3 & Mengidentifikasi hipotesis & Membuat hipotesis & 70 & 75 \\
\hline 4 & Mengumpulkan data & $\begin{array}{l}\text { Merancang penyelidikan } \\
\text { (melakukan percobaan, } \\
\text { menentukan cara mengolah data) }\end{array}$ & 70 & 73 \\
\hline 5 & $\begin{array}{l}\text { Verifikasi hasil dan penarikan } \\
\text { kesimpulan }\end{array}$ & $\begin{array}{l}\text { Mengkomunikasikan, menerapkan } \\
\text { konsep } \\
\text { menyimpulkan }\end{array}$ & 80 & 87 \\
\hline \multicolumn{3}{|c|}{ Rata-rata } & 70 & 75 \\
\hline
\end{tabular}

satu indikator, namun tidak semua indikator KPS yang dibelajarkan digunakan dalam soal. Hanya indikator menyimpulkan, mengklasifikasi dan menerapkan konsep.

Dari hasil penelitian tes tulis pada setiap siklus. Diperoleh keterangan bahwa rata-rata keterampilan proses sains siswa pada konsep larutan elektrolit dan nonelektrolit mengalami peningkatan. Peningkatan hasil belajar siswa dikelompokkan dalam kategori kelompok prestasi tinggi, sedang, dan rendah. Seperti ditunjukan dalam bentuk grafik pada Gambar 2.

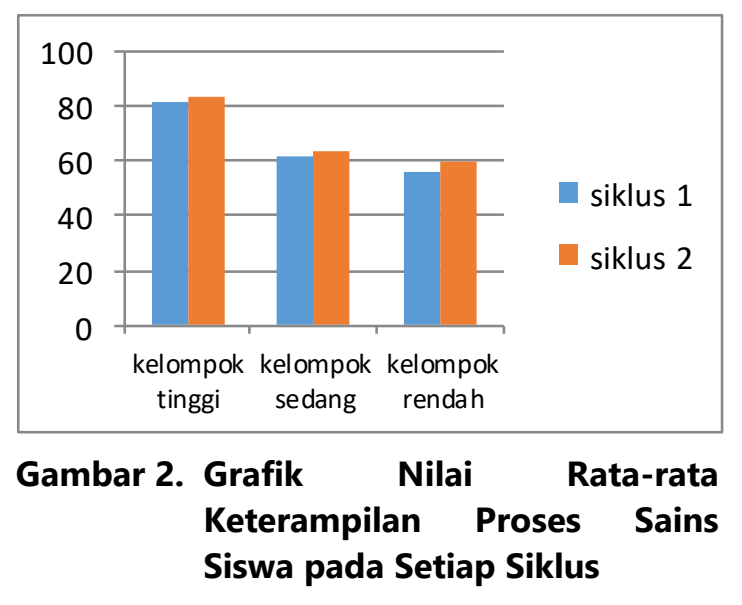

Jurnal Tadris Kimiya 3, 2 (Desember 2018): 190-198

This is an open access article under CC-BY-SA license (https://creativecommons.org/licenses/by-sa/4.0/) 
Penerapan Model Pembelajaran Inkuiri Terbimbing untuk Meningkatkan Keterampilan Proses Sains Siswa pada Konsep Larutan Elektrolit dan Nonelektrolit

Pada kelompok tinggi (siklus I sebesar 82 dan siklus II sebesar 84 ). Kelompok sedang (siklus I sebesar 62 dan siklus || sebesar 64) dan kelompok rendah (siklus I sebesar 56,2 dan siklus II sebesar 60). Data tersebut dapat memberikan informasi bahwa rata-rata keterampilan proses sains siswa pada konsep larutan elektrolit dan nonelektrolit setiap siklusnya terjadi peningkatan. Dilihat dari selisih antara nilai rata-rata keterampilan proses sains siswa pada siklus I dan II. Nilai rata-rata siklus I yaitu 67 dan siklus II yaitu 70 . Namun peningkatan nilai rata-rata siklus I dan II sangat rendah. Hal ini dikarenakan beberapa faktor, diantaranya siswa masih kurang pada pengetahuan prasyarat ditunjukkan dengan hasil nilai ulangan akhir semester gasal bahwa 60\% siswa masih berada dibawah nilai KKM. Sehingga pembelajaran masih belum bermakna, karena pembelajaran bermakna terjadi ketika pengetahuan atau pengalaman baru yang didapat siswa dapat berkait dengan pengetahuan yang lama yang sudah diketahui atau dimiliki siswa (Ausubel dalam Budiningsih, 2005).

Nilai rata-rata keterampilan proses sains secara keseluruhan pada siklus 167 dan siklus II 70 berkategori baik walaupun menghasilkan rentang yang tidak jauh berdasarkan peningkatan dari setiap siklusnya. Hal ini dikarenakan dalam pembelajaran inkuiri terbimbing siswa dituntut aktif dalam proses pembelajaran dan siswa menemukan konsep secara mandiri. Sehingga berpengaruh pada keterampilan proses sains siswa. Sejalan dengan yang dikemukakan oleh Riyanto (2010) pembelajaran yang dikemas dengan tujuan agar dapat membangun pengetahuan siswa, yaitu pembelajaran yang melibatkan siswa aktif dalam proses pembelajaran.
Berdasarkan uraian nilai rata-rata keterampilan proses sains secara keseluruhan pada siklus 167 dan siklus II 70 berkategori baik dan telah memenuhi KKM 70 di sekolah SMAN 10 Bandung. Hal ini sejalan pada hasil penelitian McDonnell (2013) yang menunjukkan bahwa dengan menerapkan pembelajaran inkuiri terbimbing dapat meningkatkan berpikir tingkat tinggi siswa yang meliputi keterampilan pemecahan masalah, keterampilan proses sains siswa dan membentuk siswa menjadi mandiri juga berpikir kritis. Secara umum dapat dikatakan bahwa model ini ternyata cocok diterapkan pada konsep larutan elektrolit dan nonelektrolit di SMAN 10 Bandung, karena di dalam pembelajarannya banyak mengajarkan siswa untuk belajar aktif.

\section{KESIMPULAN}

Aktivitas siswa dalam penerapan pembelajaran inkuiri terbimbing pada konsep larutan elektrolit dan nonelektrolit mengalami peningkatan. Pada siklus I nilai rata-rata aktivitas siswa sebesar 86,4 (sangat baik), dan pada siklus II nilai rata-rata aktivitas siswa sebesar 91 (sangat baik). Kinerja siswa dalam menyelesaikan LKS untuk setiap siklus pembelajaran inkuiri terbimbing pada konsep larutan elektrolit dan nonelektrolit mengalami peningkatan. Nilai rata-rata siklus I sebesar 70 (baik) dan nilai rata-rata siklus II sebesar 75 (baik), keterampilan proses sains siswa setelah pembelajaran inkuiri terbimbing terjadi peningkatan setiap siklusnya. Berdasarkan analisis penguasaan konsep larutan elektrolit dan nonelektrolit pada setiap siklus ditunjukkan dengan nilai rata-rata siklus I 67 (cukup) dan siklus II 70 (baik). 


\section{DAFTAR PUSTAKA}

Arikunto, S. (2013). Prosedur Penelitian. Jakarta: Rineka Cipta.

Budiningsih, A. (2005). Belajar dan pembelajaran. Jakarta: Rineka Cipta.

Calik, M. \& Ayas, A. (2005). A Comparison of Level of Understanding of Eighth-Grade Students and Science Student Teachers Related to Selected Chemistry Concepts. Journal of Research in Science Teaching, 42(6), 638-667.

Chang, R. (2005). kimia Dasar konsep-konsep inti jilid 1. Jakarta: Erlangga.

Dimyati, A. (2015). Peningkatan Kemampuan Berpikir Kritis dan Komunikasi Matematis Siswa MTS melalui Model Search, Solve, Create, and Share (SSCS) dengan Metode Hypnoteaching (Doctoral dissertation, Universitas Pendidikan Indonesia).

Farida, I. (2014). Evaluasi Pembelajaran (Penilaian Proses dan Hasil Belajar IPA). Bandung: Patragading.

Fathan, F., \& Liliasari \& Rohman, I. (2013). Pembelajaran Kesetimbangan Kimia dengan Multimedia Interaktif untuk Meningkatkan Penguasaan Konsep dan Keterampilan Berpikir Kritis Siswa SMA. Jurnal Riset dan Praktik Pendidikan Kimia, 1(1), 76-83.

Fitriyani, R., Corebima, A. D., \& Ibrohim, I. (2015). Pengaruh Strategi Pembelajaran Problem Based Learning dan Inkuiri Terbimbing Terhadap Keterampilan Metakognitif, Berpikir Kritis, dan Hasil Belajar Kognitif Siswa SMA. Jurnal Pendidikan Sains, 3(4), 186-200.
Penerapan Model Pembelajaran Inkuiri Terbimbing untuk Meningkatkan Keterampilan Proses Sains Siswa pada Konsep Larutan Elektrolit dan Nonelektrolit

Hanson, D. M. (2006). Instructor's Guide to Process-oriented Guided-inquiry Learning. Lisle, IL: Pacific Crest.

Kemendikbud. (2016). Silabus Mata Pelajaran SMA/MA Mata Pelajaran Kimia. Jakarta: Kementrian Pendidikan dan Kebudayaan.

McDonnell, J. B. (2013). The Effects of Guided Inquiry on Understanding High School Chemistry. Montana State University

McMurry, J. E. dan R. C. F. (2012). Chemistry (sixth edition). New York: Pearson Prentice Hall.

Mulyasa, E. (2011). Menjadi Guru Profesional. Bandung: PT. Remaja Rosdkarya.

Putra, R. (2013). Desain Belajar Mengajar Kreatif Berbass Sains. Yogyakarta: DIVA Press.

Riyanto, Y. (2010). Paradigma Baru Pembelajaran. Jakarta: Kencana Persada Media Group.

Warsono, H., \& Hariyanto, M. S. (2012). Pembelajaran Aktif Teori dan Asesmen. Bandung: PT Remaja Rosdakarya. 